\title{
ESPAÇOS PÚBLICOS, LAZER E CIDADE: CONFORMAÇÃO DE PRAÇAS PÚBLICAS EM BELÉM-PARÁ
}

\author{
Jessika Paiva França ${ }^{1}$ \\ Mirleide Chaar Bahia ${ }^{2}$
}

\begin{abstract}
RESUMO
Este artigo identifica alguns acontecimentos marcantes na cidade de Belém-Pará, os quais influenciaram na produção e reconfiguração de Espaços Públicos, em especial na conformação dos largos que, atualmente, são mais conhecidos pela denominação de Praças Públicas. Para tanto, utilizou-se de ampla pesquisa bibliográfica e documental sobre a fundação e expansão urbana da cidade de Belém. Os resultados apontaram que, por aproximadamente dois séculos, a institucionalização desses espaços esteve vinculada a interesses religiosos de consolidação do catolicismo, por favorecer a aglutinação de pessoas. Somente no final do século XIX, foram denominados de praças e passaram a servir, mais fortemente, às práticas de lazer e de sociabilidade na cidade.
\end{abstract}

Palavras-chave: Praças Públicas. Espaços Públicos. Lazer. Belém-Pará.

\section{RESUMEN}

Este artículo identifica algunos eventos notables en la ciudad de Belém-Pará, que influyeron en la producción y reconfiguración de espacios públicos, especialmente en la conformación de las plazas que ahora se conocen mejor con el nombre de Plazas públicas. Para ello, utilizamos una amplia investigación bibliográfica y documental sobre los cimientos y la expansión urbana de la ciudad de Belém. Los resultados mostraron que, durante aproximadamente dos siglos, la institucionalización de estos espacios estuvo vinculada a intereses religiosos de consolidación del catolicismo, para favorecer la aglutinación de personas. Solo a fines del siglo XIX, se llamaron plazas y comenzaron a servir, con mayor fuerza, a las prácticas de ocio y sociabilidad en la ciudad.

Palabras clave: plazas públicas. Espacios publicos. Ocio Belém-Para.

\section{INTRODUÇÃO}

A fundação da cidade de Belém, assim como a maioria das cidades brasileiras litorâneas, a citar Natal, Salvador e Recife, esteve ligada à construção de uma fortificação, com fins de proteção territorial. De acordo com Moreira (1966), em 1616, o Forte do Presépio foi edificado às margens do Rio Guamá, em uma parte mais elevada do território e com significativo isolamento da área continental, em decorrência das áreas alagadas que o

\footnotetext{
${ }^{1}$ Doutora em Arquitetura e Urbanismo pelo Programa de Pós-graduação em Arquitetura e Urbanismo do Instituto de Arquitetura e Urbanismo da Universidade de São Paulo (USP). Professora da Faculdade de Turismo do Instituto de Ciências Sociais Aplicadas (ICSA) da Universidade Federal do Pará (UFPA).

${ }^{2}$ Doutora em Ciências: Desenvolvimento Socioambiental pelo Programa de Pós-graduação em Desenvolvimento Sustentável do Trópico Úmido (PPGDSTU) do Núcleo de Altos Estudos Amazônicos (NAEA) da Universidade Federal do Pará (UFPA). Professora do Núcleo de Altos Estudos Amazônicos (NAEA) da Universidade Federal do Pará (UFPA).
} 
circundavam. As irregularidades no nivelamento do território, apresentando baixa elevação, eram extremamente propícias aos alagamentos. O clima úmido e chuvoso da região mantinha as áreas alagadas durante o ano inteiro, em forma de igapó. Para Corrêa (1989), o maior de todos os alagados localizava-se no entorno do Forte, recebendo dos índios a denominação de Piry, também conhecido como Juçara, desta forma escrito em alguns registros da época.

Águas paradas, aves multicores, ambiente tranquilo e soberbo de verdejantes mururés compunham o Piry que os nativos denominavam de baixios da Juçara, para caracterizar o igapó que originava a formação do "lago", criando uma enorme bacia alagada no interior da urbe (FILHO, 1976, p. 153).

A ilustração abaixo, representativa da evolução urbana no século XVII, revela o Forte enquanto eixo fundacional do vilarejo, cercado pelo Rio Guamá e o alagado Piry.

Figura 1: Início do processo de urbanização de Belém (fins do século XVII).

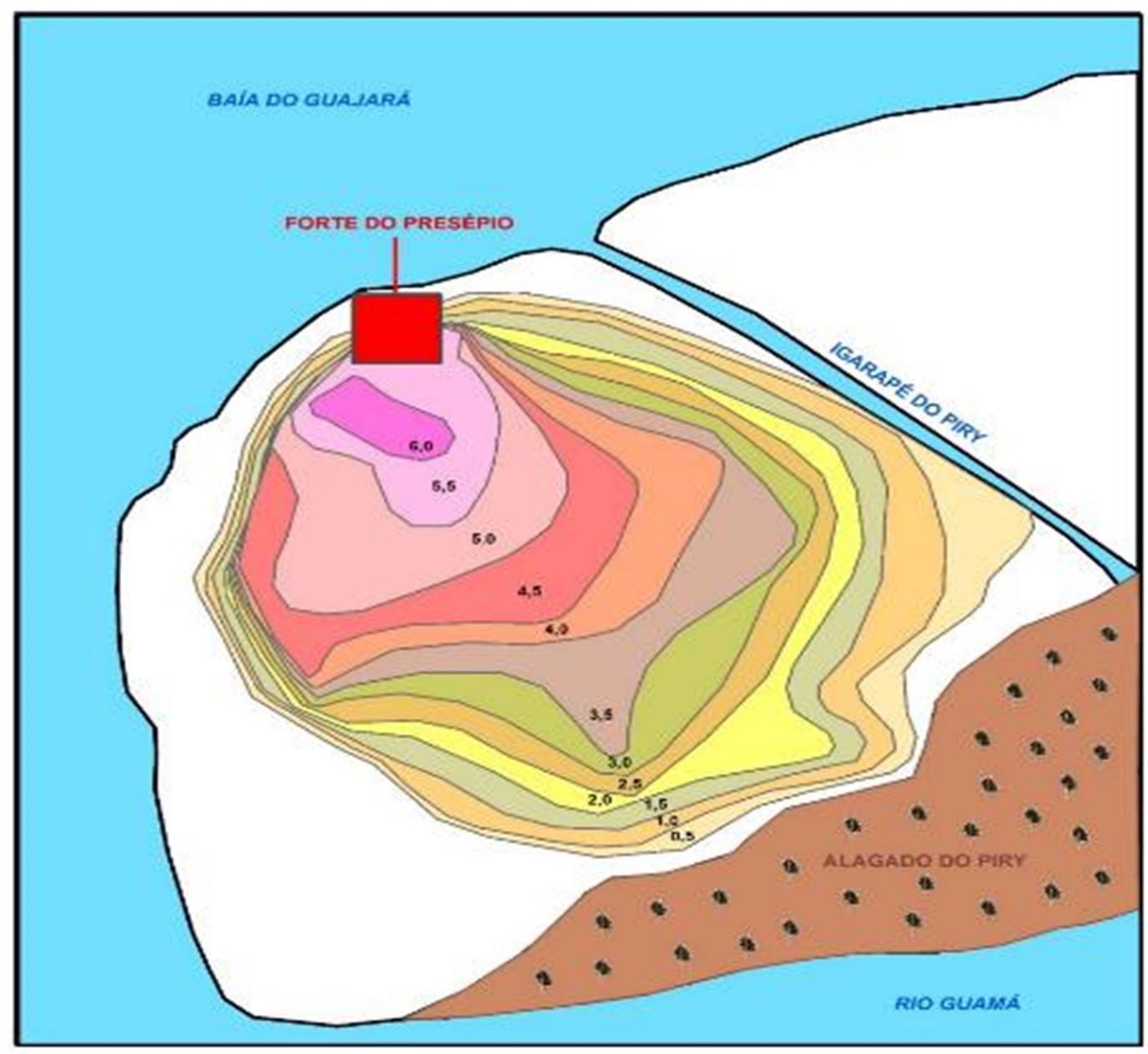

Fonte: França (2018). Adaptado a partir do trabalho de Corrêa (1989). 
O pequeno vilarejo foi progredindo lentamente em seu avanço territorial, com uma composição espacial marcada por chão de terra batida, cercado por grandes áreas, progressivamente baixas (partindo do Forte em direção ao interior), conforme é possível observar na imagem acima. Neste mapa, o Forte aparece no ponto de maior elevação da nascente cidade. "Belém começava a dilatar-se para além das muralhas frágeis de madeira trançada que circundavam o forte, fixando seus limites e garantindo sua proteção" (FILHO, 1976, p. 59).

As primeiras igrejas e conventos de Belém foram edificadas a partir do Forte do Presépio, seguindo em direção ao interior da cidade, como forma de apoio à expansão territorial objetivada pela Coroa Portuguesa. Eram erguidas em grandes terrenos descampados, com arquitetura simples, utilizando, em muitos casos, palha, pedra e barro. Estas eram construídas sempre interligadas ao eixo inicial da cidade, onde o largo assumia um papel periférico, pois era utilizado como um espaço complementar das mesmas, para fins de organização da vida social, por meio da coesão dos fiéis, sem que houvesse fins do que se denomina atualmente de lazer, especificamente.

Era costume na instituição das igrejas que se reservassem dois espaços imediatos em sua frente: o pátio, considerado de uso privativo para eventos religiosos e adiante o largo, para frequência popular em romarias (SOARES, 2009, p. 26).

É importante destacar que a categoria lazer é aqui abordada enquanto fenômeno sociocultural, existente em diferentes sociedades e espaços. Neste contexto, a vivência sociocultural do lazer não se encontra condicionada à rígida disposição socioespacial da época citada.

O Forte do Presépio, mesmo em sua precariedade em termos de construção, foi considerado um largo aglutinador, por comportar o primeiro espaço religioso de Belém, dedicado à Nossa Senhora das Graças. O Largo das Armas (Foto 1) funcionou no centro da fortificação, sendo visto por alguns estudiosos, como "[...] o primeiro largo da nova terra" (SOARES, 2009, p. 13). 
Figura 2: Largo das Armas no Forte do Presépio.

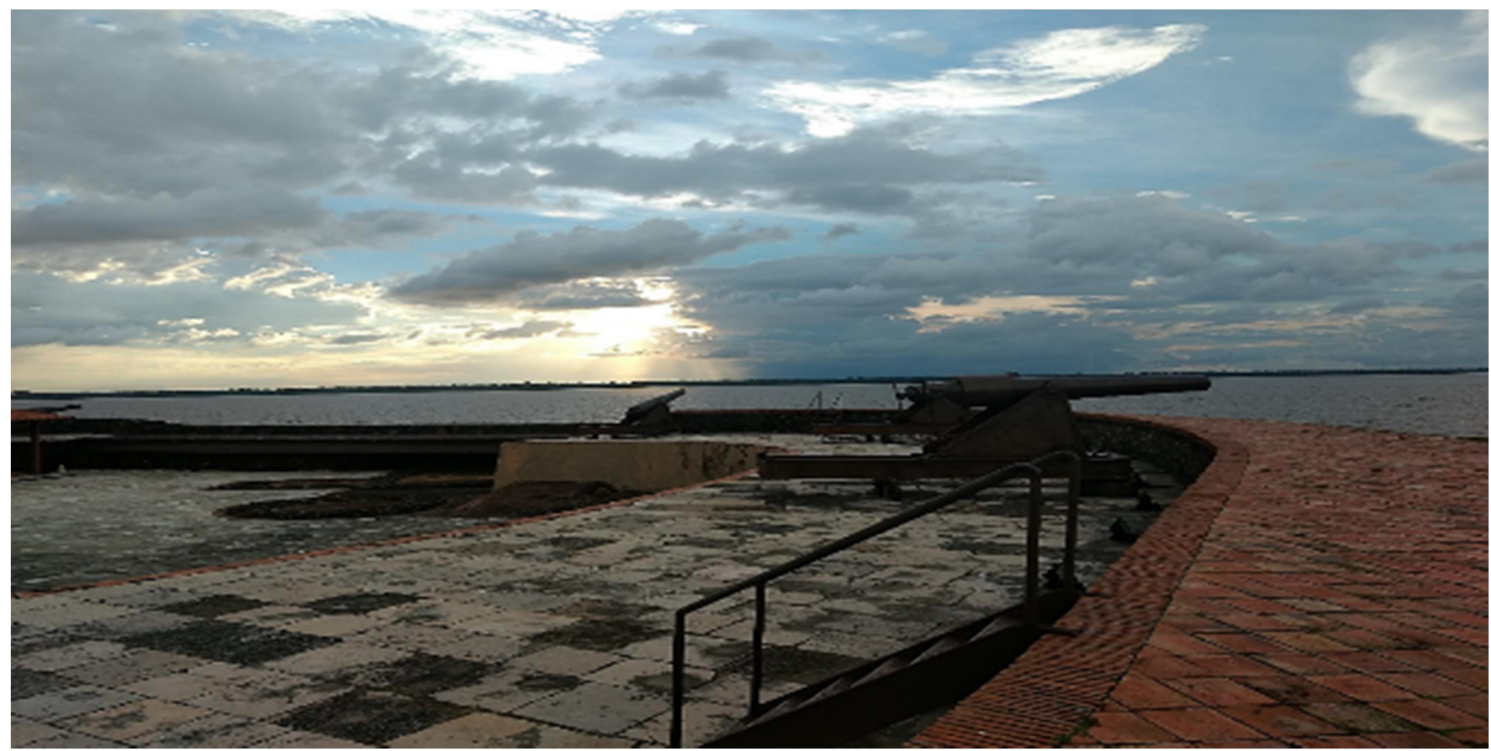

Fonte: Jéssika França (2018).

Após a reforma na estrutura física do Forte, o templo religioso de N. Sa. das Graças ganhou nova sede, mas continuou às proximidades do Forte, distante poucos metros. Em frente à nova igreja, havia uma área descampada, que deu origem ao segundo largo da cidade: O Largo da Matriz, no ano de 1619 (SOARES, 2009). Atualmente, é mais conhecido como Largo da Sé e Praça Frei Caetano Brandão, em continuidade à igreja Matriz Nossa Senhora das Graças, hoje nomeada de Catedral Metropolitana de Belém ou Catedral da Sé.

Esta modificação tratou-se de uma tentativa de expansão do vilarejo e adequação aos hábitos culturais dos colonizadores. "[...] a construção para a nova ermida, marcaria para a posteridade, desde 1619, o centro de toda a irradiação construtiva da futura cidade de Belém" (FILHO, 1976, p. 126). Neste sentido, a expansão urbana teve como ponto de partida o eixo fundacional, seguindo em direção ao interior, onde as ruas abertas sempre convergiam ao centro.

Como todas as atividades realizadas pela sociedade, na época, tinham o Forte como ponto inicial ou final, as ruas foram traçadas com o intuito de possibilitar o seu acesso, seguindo um modelo português, de hierarquização a partir de edificações religiosas com algumas adaptações à topografia local, resultando na composição de caminhos e ruas tortuosas. "Em 1619, soldados, colonos e índios trabalharam conjuntamente no processo de fortalecimento da colônia, buscando caminhos mais distantes do Forte, resultando nas primeiras ruas, a citar: Rua do Norte, Rua do Espírito Santo, Rua dos Cavaleiros, Rua de São João" (VALENTE, 1993, p. 11). 
A estrutura urbana apresentava, neste período, ruas estreitas e irregulares, nas quais prevalecia a existência de casas com um único pavimento de taipa ou eram revestidas de barro. Este era considerado por estudiosos, como Penteado (1968) e Moreira (1989), um desenvolvimento urbano próximo do que se pode chamar de "espontâneo". Eidorfe Moreira (1989) acredita que o crescimento aditivo da cidade conduziu a uma certa irregularidade no traçado urbano, revelado no desenho das quadras. Há predominância das linhas retas, que em muitas situações ignoraram a singularidade geográfica local, marcada por alagamentos.

Ainda nas primeiras décadas após a fundação, alguns santos padroeiros foram homenageados, por meio de cultos, procissões e festividades, se expandindo pelas novas igrejas e construindo, processualmente, relações de identidade com a população originária local. Igrejas, largos e ruas da crescente cidade constituíam-se em lócus desses acontecimentos.

\begin{abstract}
A partir de 1626, no Largo de São João, de caráter altamente festivo, iniciou-se a promoção dos portugueses em 24 de junho, com enorme adesão dos tupinambás, que participavam com grande alegria em meio à animação com fogueiras, danças e, certamente, atrevimentos alcoólicos. Houve, portanto, coincidência entre o propósito católico de atrair os índios ao convívio missionário catequético e as práticas rituais indígenas, simbolizadas pelas fogueiras de São João. Talvez seja por causa disso que os festejos juninos tenham tomado a proporção e a importância que ganharam no calendário festivo (SOARES, 2009, p. 33).
\end{abstract}

A disseminação de largos, como ampliação territorial das igrejas, teve continuidade nos anos seguintes, quando em 1751, Francisco Xavier de Mendonça Furtado assumiu o governo, dando continuidade à institucionalização dos largos como espaços de extensão do poder religioso, com fins apenas de aglutinação de pessoas para a realização de atividades voltadas à consolidação do catolicismo. Somente em fins do século XIX, é que os largos passam a receber a denominação de praças públicas e com isso, passam a ser associados ao que se nomeia atualmente de lazer.

O projeto urbanístico do governador, apesar de manter a institucionalização dos largos, continha a filosofia urbana portuguesa de que eles eram apenas espaços para ajuntamento público, sem necessidade de se transformar em recantos de lazer e encontros, o que só aconteceria posteriormente (SOARES, 2009, p. 34).

Juntamente com a expansão da cidade, por meio do adentramento ao interior, é que surgem os primeiros largos como extensão de prédios públicos institucionais, que sediaram as administrações governamentais. 
Neste contexto, cabe um adendo sobre os tipos e formas de lazer que coexistiram neste período, mas que por motivos escusos não ganharam destaque nos registros documentais elaborados nos dois primeiros séculos posteriores à fundação da cidade. Apenas as formas de sociabilidade desenvolvida pelas elites são apresentadas com algum destaque, ocultando quase que completamente as manifestações das camadas populares. Estas quase sempre, foram associadas à desordem social.

É possível inferir que as manifestações não formais de lazer sempre estiveram presentes nas diferentes disposições socioespaciais. O crescimento e desenvolvimento urbano da cidade de Belém apenas demarcou à prática de utilização dos espaços públicos para esse fim. É certo que as manifestações das camadas populares foram reprimidas, sem, contudo, deixarem de resistir nos espaços não formais, como é possível citar os lares, terreiros e áreas mais afastadas do centro da cidade. As atividades cotidianas desempenhadas na cidade pelas camadas populares como por exemplo, as rodas de conversas, trocas comerciais, o banho de rio, pesca, lavagem de roupa e brincadeiras foram combatidas pelo poder dominante. Não eram entendidas como lazer, mas sim como estratégias populares de enfrentamento.

A seguir, observa-se o Mapa 1, assinado por Penteado (1968), revelador de uma ampliação da ocupação territorial, que ultrapassou os limites do alagadiço. Novas ruas e travessas foram abertas, ocupadas por edificações com diversos fins, além de religiosos e habitacionais, transformando, sobremaneira, o desenho de cidade neste século. É possível observar a divisão dos dois núcleos, Cidade e Campina, pelo alagado Piry. 
Mapa 1: Belém nos fins do séc. XVII.

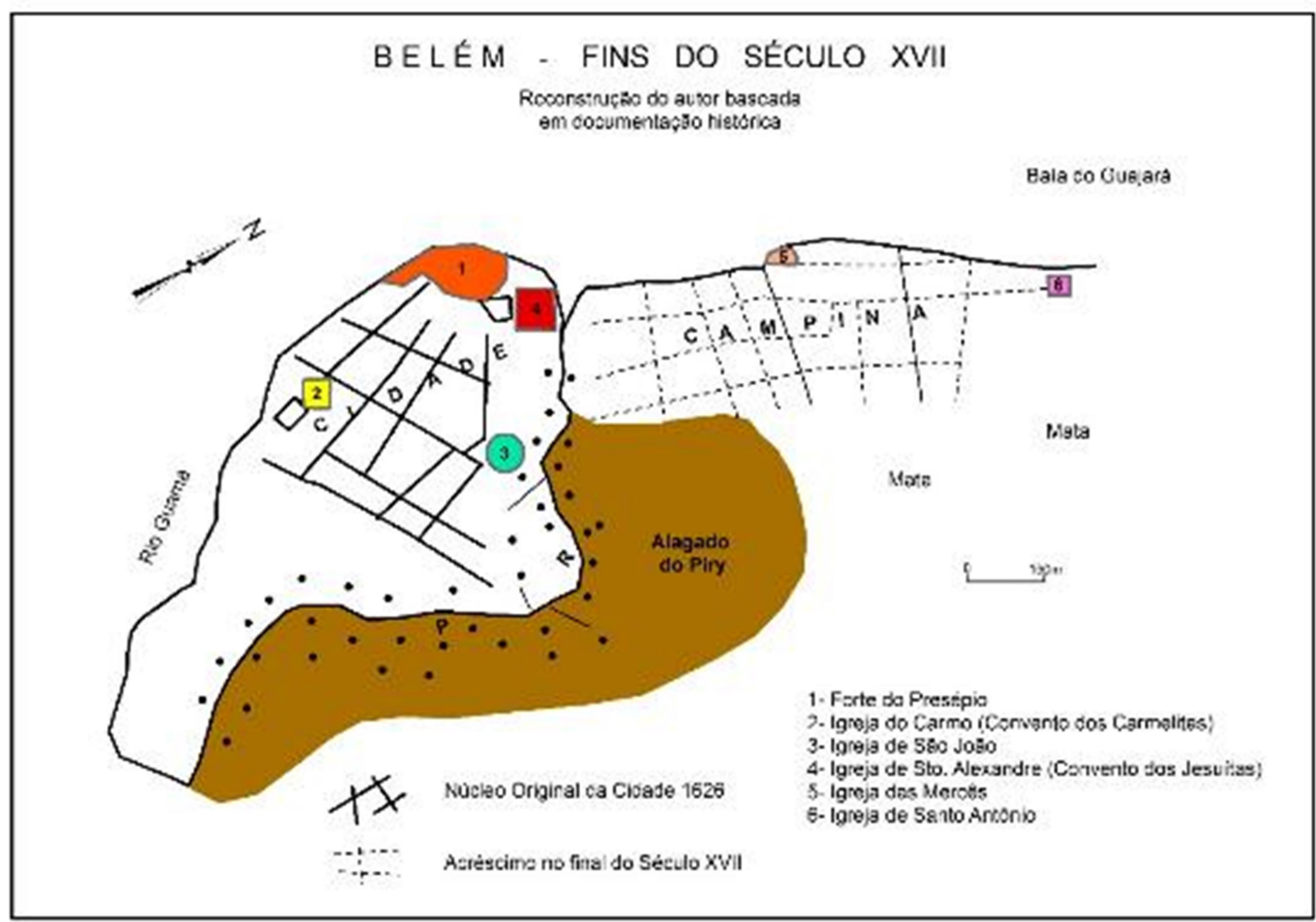

Fonte: França (2018), adaptado a partir do trabalho de Penteado (1968, p. 101).

Com a conformação do núcleo da Campina, houve uma transferência de parte da população e dos espaços de decisões políticas, religiosas e econômicas do núcleo da Cidade para o novo espaço.

Segundo Souza Ferreira, por volta de 1685, Belém já possuía quinhentos habitantes e ao final do século XVIII a cidade já registra 10.620 hab. Ao findar o século XVII, já era possível distinguir os dois núcleos iniciais da cidade, separados pelo Pirí. Sendo que o da cidade ficava junto ao Forte do Presépio (SARGES, 2000, p. 42).

Juntamente com o crescimento populacional e a expansão territorial, para além do primeiro núcleo da cidade, as relações comerciais começaram a exigir novas alternativas de intermediação na sociedade local. É quando, no ano de 1749, o dinheiro amoedado começa a circular.

Neste contexto do século XVIII, a expansão urbana local tinha o rio e as áreas alagadas como um fator impeditivo, sendo apresentado com detalhes por Almeida (2011), que faz uma análise sob o viés de utilidade. 
enfermidades, ou ainda, obstáculos a serem superados. Os dirigentes provinciais assim pensavam e nos jornais que circularam na Belém dos oitocentos, os textos reproduziam esse modo de pensar, não raramente expressando o pensamento médico. Todavia, possivelmente para aqueles que mantinham uma convivência rotineira e de longa data com aquelas áreas, estas não se constituíssem em lugares pestíferos. Relativamente a essa questão, nos anos quarenta, Bates anotou a presença de lavadeiras e aguadeiros, os quais se dirigiam às áreas baixas e pantanosas da cidade para lavar roupas e encher pipas d'água, o que implicava certamente, em idas e vindas pelos ditos terrenos baixos e pantanosos da cidade de Belém (ALMEIDA, 2011, p. 7).

As principais atividades das classes populares que foram identificadas nos livros e registros históricos, são manifestações culturais especialmente originárias dos negros e índios, e estiveram em grande parte associadas aos banhos de rio. No entanto, permaneceram durante longo período na clandestinidade, sendo proibidas pelo poder público local.

Vale enfatizar que o imaginário ocidental sobre o uso das águas marítimas para fins de saúde e lazer entre os séculos XVIII e XIX é muito bem abordado por Alain Corbin (1989, p.23), que traça uma linha do tempo, revelando os principais acontecimentos históricos que somaram para a construção de um valor pejorativo destinado ao mar. As grandes expedições se constituíram em um grande desafio ao homem, que precisou passar longos períodos navegando e enfrentando dificuldades como fome, pestes, enjoos e tempestades, que eram interpretadas, na época, pelos viajantes como um a fúria do mar.

Corbin (1989) afirma que antes do século XVIII as representações sociais sobre o mar eram permeadas por sentimentos de repulsa, muito associadas a naufrágio de embarcações, proliferação de doenças e mal cheiro, além de enjoos causados pelas longas viagens. Os avanços nas técnicas de navegação contribuíram para um repensar quanto ao papel do mar e suas praias para a saúde e lazer da sociedade. Em meados do século XVIII, o mar e o banho em praias passam a ser associados a fins medicinais. "Doravante espera-se do mar que acalme as ansiedades da elite, que restabeleça a harmonia do corpo e da alma, que estanque a perda de energia vital de uma classe social” (CORBIN, 1989, p.74).

\section{A PRODUÇÃO URBANA APÓS O ATERRAMENTO DO ALAGADO DO PIRY}

No século XIX, entre os anos de 1803 e 1806, as obras de aterramento foram realizadas; isso ocorreu durante a gestão de Dom Marcos Noronha Brito. A falta de conhecimento sobre métodos e técnicas de aterramento, além da ausência de recursos, resultou no adiamento em quase dois séculos do desaguamento do Piry, previsto no plano de expansão da cidade como essencial aos avanços. 
O Mapa 2 é representativo da ocupação da Primeira Légua Patrimonial de Belém, nos séculos XVII, XVIII e XIX, partindo do Forte em direção ao interior da cidade. Em 1650, observa-se uma ocupação concentrada ao entorno da fortificação, progredindo lentamente, em direção ao interior, durante o século XVIII. Com o desaguamento e aterramento do Piry, no século XIX, ocorre uma expansão mais significativa do espaço intraurbano, no ano de 1886. 
Mapa 2: Ocupação urbana de Belém ao longo dos séculos XVII a XIX.

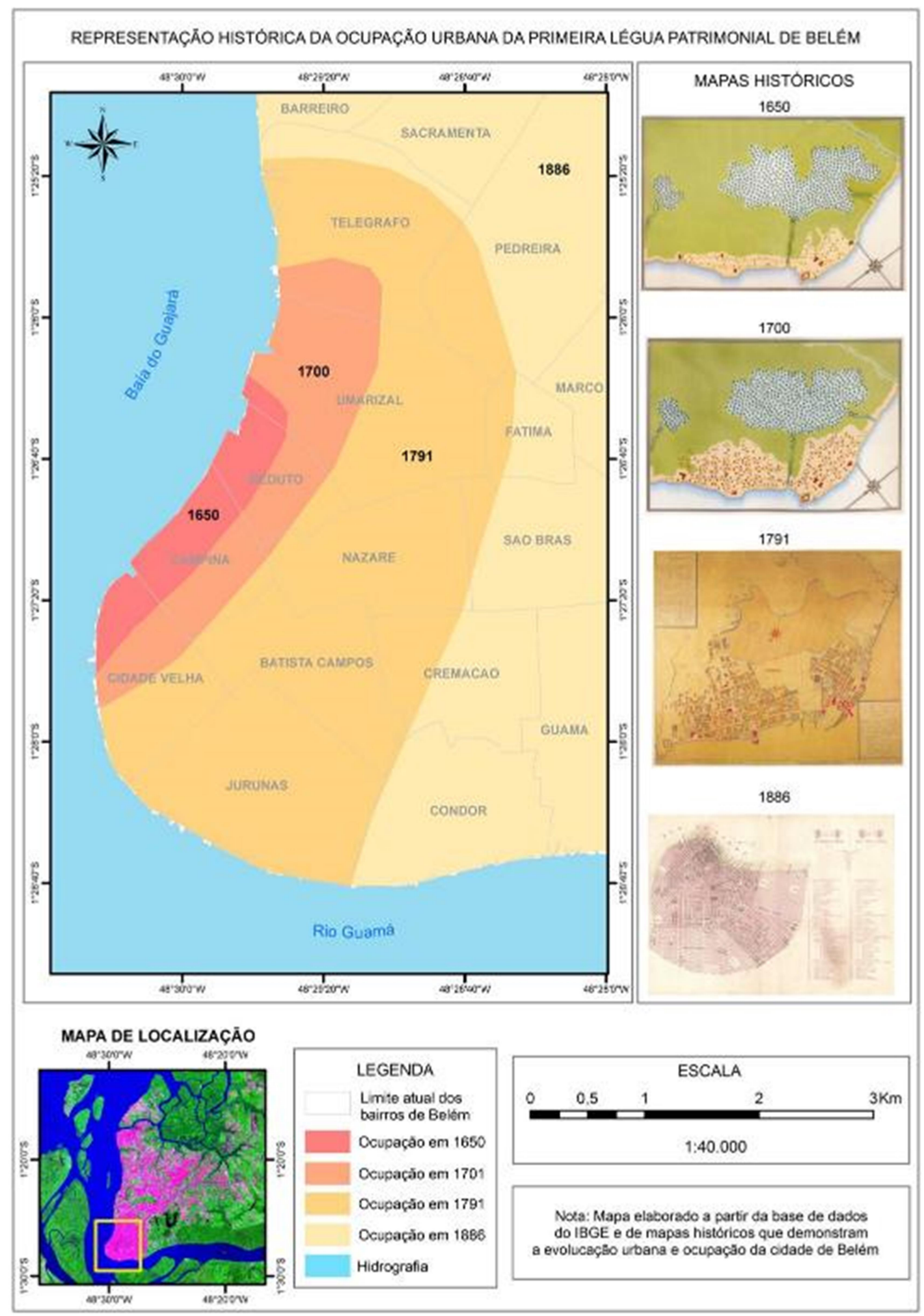

Fonte: França (2018). 
A área aterrada, limítrofe entre os dois núcleos, deu lugar à construção da Praça Dom Pedro II, conforme pode ser visto na Foto 3 abaixo.

Foto 3: Praça Dom Pedro II.

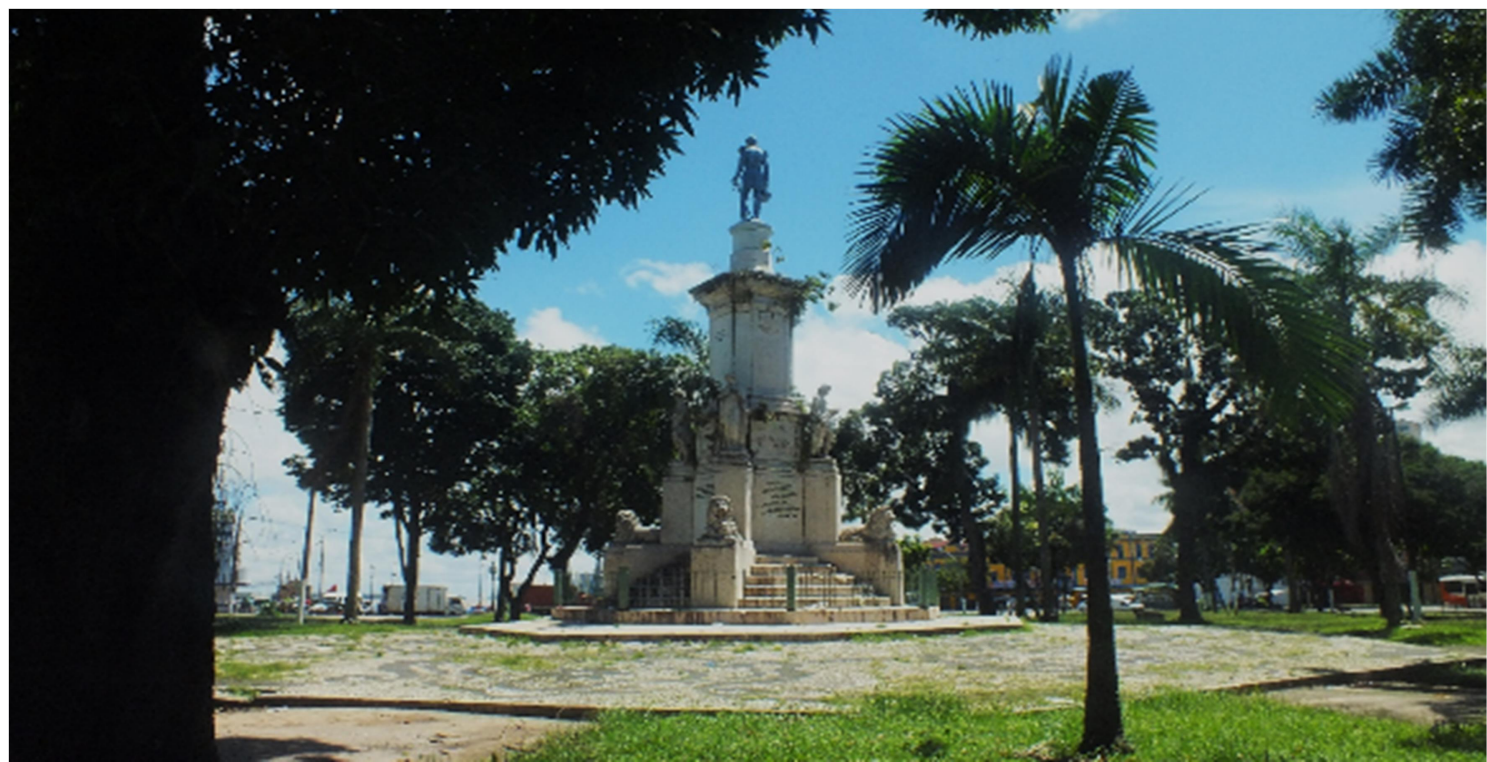

Fonte: Jéssika França (2018).

A Praça D. Pedro II, localizada às proximidades do Forte do Presépio, contribuiu ao embelezamento urbano da área onde antes existia o alagadiço Piry. É um espaço representativo na história da produção urbana local.

Outra consequência deste aterramento foi a ampliação do desejo por construção de segunda residência, especialmente pela classe abastada. As rocinhas expandiram-se, associadas ao desejo de sossego e contemplação voltados a um maior contato com a natureza, conforme observa-se no fragmento de Tocantins (1987):

Rigorosamente falando era o todo que formava a pequena propriedade rural: campo, floresta, pomar e casa. Mas, na linguagem usual significava a vivência da cercada de árvores silvestres, de fruteiras, de jardins rústicos, na paz dos subúrbios. Isto no começo do século dezenove, quando no auge o prestígio das rocinhas belemense, decantadas pelos estrangeiros visitantes, caídos de amores por elas (TOCANTINS, 1987, p. 152).

O desejo de fuga da dinâmica urbana e da rotina de trabalho já era percebido na sociedade local, que vislumbrava, nas rocinhas, o desejo por atividades em ambiente familiar, ao mesmo tempo em que envolvia a necessidade de deslocamento entre espaço de moradia e de segunda residência. Desta forma, a rocinha diferenciava-se do espaço habitual. 
A rocinha é apenas um dos elementos sinalizadores dessa produção urbana na época, haja vista que a expansão da cidade é resultante de um movimento social, político e econômico. Neste sentido, considera-se que a produção dos bens materiais e imateriais é reflexo de um movimento político norteador que se manteve após o período, se estendendo aos dias atuais.

\section{O CONTEXTO HISTÓRICO DO CICLO DA BORRACHA, AS INTERVENÇÕES DE ANTÔNIO LEMOS NO ESPAÇO PÚBLICO E A CONFORMAÇÃo DAS PRAÇAS PÚBLICAS}

No período compreendido entre 1840 a 1920, a Amazônia ganhou destaque no âmbito do capitalismo mundial, em decorrência da economia da borracha, período em que Belém transformara-se na principal responsável pelo escoamento da produção para as demais cidades e países, passando por um processo de modernização, na segunda metade do século XIX.

Os impactos ultrapassaram os limites de Belém e Manaus, refletindo na dinâmica econômica nacional. Neste sentido, pode-se afirmar que é a partir do ciclo da borracha que o aumento populacional e a expansão urbana, em direção ao interior da parte continental, são ampliados. Em 1872, existiam 61.997 habitantes, levando Belém a se posicionar entre as cinco cidades com maior população urbana no país.

No fim do século XIX, foi implantado o sistema de bondes elétricos e iluminação pública, pela empresa inglesa Pará Eletric Railways and Lighting, favorecendo, sobremaneira, a mobilidade econômica e social, além de impactar na construção civil (STIEL, 1984). No entanto, o bonde revelou fragilidade para o transporte de carga pesada, fazendo com que a gestão pública local tomasse providências quanto à construção de um Porto, no ano de 1906.

O bonde apresentava maior dinamicidade e frequência no eixo central servindo, prioritariamente, para fins de mobilidade da população. Contudo, havia uma crescente necessidade de meios de transportes que servissem ao abastecimento local, dando fluidez à dinâmica econômica da produção gomífera.

Havia um fluxo mais intenso da linha de bondes nos bairros da Cidade Velha, Campina, Reduto, Nazaré, Batista Campos e Umarizal, beneficiando os seus moradores, em termos de mobilidade urbana. Nos bairros de São Brás, Canudos e Marco, a linha de bondes apresentava um trajeto único, cortando a cidade, objetivando a interligação do eixo central 
com a cidade de Bragança ${ }^{3}$. Havia também vários bairros não contemplados com a linha de bondes, a citar: Telégrafo; Pedreira; Fátima; Terra Firme; Canudos; Cremação; Condor; Universitário. Nos bairros do Guamá e Jurunas, era possível ter acesso a este transporte, em um único ponto.

Vale enfatizar a dinamização urbana decorrente da gestão de Lemos iniciada em 1897 até 1911. Ele trabalhou no sentido de transformar a cidade em um ambiente menos insalubre, por meio de ações variadas e interligadas, dentre elas, cita-se: a abertura e o alargamento de avenidas e travessas ( $44 \mathrm{~m}$ e $22 \mathrm{~m}$ ); calçamento de ruas, favorecendo a circulação de pessoas, do ar e do sol, em bairros e quarteirões; inauguração dos serviços de incineração completa do lixo; fiscalização pública para a segurança e limpeza; implantação de uma rede d'água; arborização das praças e avenidas, para melhorar a qualidade ambiental, dentre outras intervenções (SARGES, 2002). Neste momento percebe-se um fomento da gestão pública, no que tange à construção de uma cultura de utilização das praças, especialmente para fins de passeio e de contemplação da paisagem.

O fragmento abaixo, de Tocantins, faz referência aos espaços públicos no início do século XX.

Eles aí estão (os parques e jardins) a oferecer à população o refrigério, a frescura, a tranquilidade, nas horas mais calmosas do dia. À noite, são um inestimável encanto, com a sua profusa iluminação: parecem verdadeiros cenários de mágicas estonteadoras as praças de Belém. Quisera eu poder incutir no âmbito dos munícipes a convicção de todo o bem que lhes pode fazer o passeio e o exercício nas praças, pelas horas mais próprias, haurindo o ar oxigenado dos arvoredos, o eflúvio maviosíssimo dos arbustos cheirosos e das flores (TOCANTINS, 1987, p. 141).

O desenho urbano local sofreu influência francesa de Georges Eugène Haussmann, que atuou na urbanização de Paris, entre os anos de 1853 e 1870. A intendência de Antônio Lemos $^{4}$ apropriou-se desta experiência francesa, para dar um ar de cidade moderna a Belém e, para isso, tratou a pobreza e a insalubridade com intervenções na saúde pública, saneamento e paisagismo, focando na Primeira Légua Patrimonial (LOBATO, 2005).

Antônio Lemos considerava a Primeira Légua Patrimonial a área mais importante, por compor o centro da cidade e abranger um público de moradores de alta renda, em detrimento às áreas periféricas. De acordo com Lobato (2005), a população pobre foi expulsa do centro,

\footnotetext{
${ }^{3}$ A Estrada de ferro Belém (EFB) entrou em operação no ano de 1884, mas somente em 1908 passou a operar até a cidade de Bragança, distante $222 \mathrm{~km}$ do município de Belém. Esteve ativa até a década de 1960 do século XX. Ver Andrade (2010).

${ }^{4}$ Esteve na intendência municipal de Belém entre os anos de 1897-1911, sendo reconhecido por suas intervenções voltadas à renovação estética e de higiene no ambiente urbano, sob influências europeias. Foi responsável pela criação de códigos de conduta, para reger o comportamento da sociedade nos espaços públicos. Ver Belém (1902).
} 
partindo em direção às áreas mais desprivilegiadas em termos de intervenções urbanísticas como, por exemplo, as áreas alagadas, denominadas de baixadas.

Houve nesta época muitas ações no sentido de regulamentar as edificações, tratar a incineração das imundícies, aterrar e drenar os pântanos, fechar os matadouros, além de construir um espaço para enterrar os mortos da crescente população. Em janeiro de 1901, foi construída uma grande usina crematória, localizada entre a Travessa Vinte e Dois de Junho e Nove de Janeiro, utilizando tecnologia avançada, oriunda da Inglaterra, que tratava a fumaça produzida, evitando a poluição urbana.

O governo havia mandado construir, nos arrabaldes da cidade, instalações apropriadas para os presos e doentes mentais, reduzindo-se assim a visibilidade destes segmentos destoantes na cidade reordenada e asseptizada do início do século. A fiscalização médica, sob ordens do Intendente Antônio Lemos, atuava também na fiscalização sobre a alimentação pública, para verificar as condições de higiene de produtos como peixe, carne, leite, entre outros (BELÉM, 1902). Belém foi abastecida por água potável, proveniente de poços e bicas, até o fim do século XVII, e passou a contar com um sistema mais moderno de abastecimento e distribuição em ferro fundido apenas em 1905.

Os reflexos da economia da borracha ultrapassaram as fronteiras da região, atingindo as cidades brasileiras, impactando-as em termos de renovação urbana e estética. Em Belém, os logradouros públicos ganharam contornos arquitetônicos, característicos das cidades que desempenhavam grandes papéis na economia mundial. Em seus projetos, focou na melhoria urbanística da cidade, por considerar um atraso o sistema de edificações, totalmente desprovido de beleza, o que prejudicaria a imagem da cidade. Por este motivo, a legislação municipal tratou de apresentar diretrizes e regras para as novas construções, sob a necessária apresentação de plano de construção de prédios, sendo esta, uma condição para a obtenção de licença. Os moradores locais tinham que, em suas residências, respeitar as normas de estética da cidade; caso contrário, eram afastados do centro (BELÉM, 1902).

Houve uma perceptível organização do espaço urbano, que foi acompanhada de modificações nos hábitos culturais. Os cronistas dos jornais "A Província do Pará" e "O Liberal do Pará”, sob influências políticas, faziam comentários antagônicos sobre o Theatro da Paz e sua estrutura e beleza. Certamente a política influenciou no modo de ver e utilizar os espaços públicos de lazer na cidade.

Um cronista da época faz comparação da Belém de 1900 a uma pequena Paris. No bom-gosto, no luxo, no movimento comercial, na intimidade com os vícios elegantes da civilização, na propensão à cultura brasileira que reúne os atrativos de uma cidade europeia (TOCANTINS, 1987, p. 139). 
A cidade de Belém ${ }^{5}$ foi representativa dos interesses progressistas das elites locais, como seringalistas, comerciantes, fazendeiros e investidores estrangeiros, sedentos por renovações significativas na cidade em que habitavam, o que, consequentemente, gerou o afastamento das classes populares dos limites urbanos, tão bem delimitado pelos detentores de poder. Neste contexto, a localização de grande parte dos espaços públicos de lazer nas áreas centrais (altas) da cidade é explicada por fatores inicialmente históricos e, posteriormente, estratégicos.

Os hábitos e costumes da nascente elite estampavam uma segregação social, visualizada facilmente nos espaços que possibilitavam o lazer na cidade. Belém esbanjava fartura e progresso: “[...] existiam os cafés, os teatros, as mulheres vindas de todas as partes do mundo, atraídas pelo dinheiro que rolava de mão em mão, à solta" (CRUZ, 1973, p. 424). A prosperidade possibilitada pela economia gomífera gerou uma aproximação sociocultural de algumas cidades, como Belém e Manaus com a Europa, por serem consideradas como os principais pontos de escoamento do produto.

De acordo com Bahia (2012), seguindo fielmente os princípios da obra de Haussmann, Antônio Lemos procurou imprimir em Belém ares de uma cidade moderna, com características de uma época conhecida como Belle Époque, materializados em construções de boulevards, de praças, de jardins, de bosques e a abertura de longas e largas avenidas. Mas, esse "progresso" era visivelmente direcionado apenas à área central da cidade, onde geralmente quem habitava era a elite local e parte da classe média em crescimento.

Foram construídos ou reestruturados e reinaugurados alguns dos principais espaços e equipamentos de lazer da cidade, como: cafés; casas de espetáculos; o Theatro da Paz (Foto 3); o cinema Olympia; vários largos ou praças, como a Praça da República e a Praça Batista Campos (Foto 4), assim como o Bosque Rodrigues Alves, inicialmente denominado de Bosque Municipal. Com o objetivo de proporcionar o entretenimento da classe burguesa paraense, Lemos mandava buscar grandes companhias artísticas da França, de Portugal e do Rio de Janeiro, para se apresentarem no Theatro da Paz (BAHIA, 2012).

\footnotetext{
${ }^{5}$ As cidades de Belém e Manaus foram as mais impactadas pela economia gomífera no âmbito nacional. Ver Tocantins (1987).
} 
Foto 4 - Salão Nobre do Theatro da Paz.
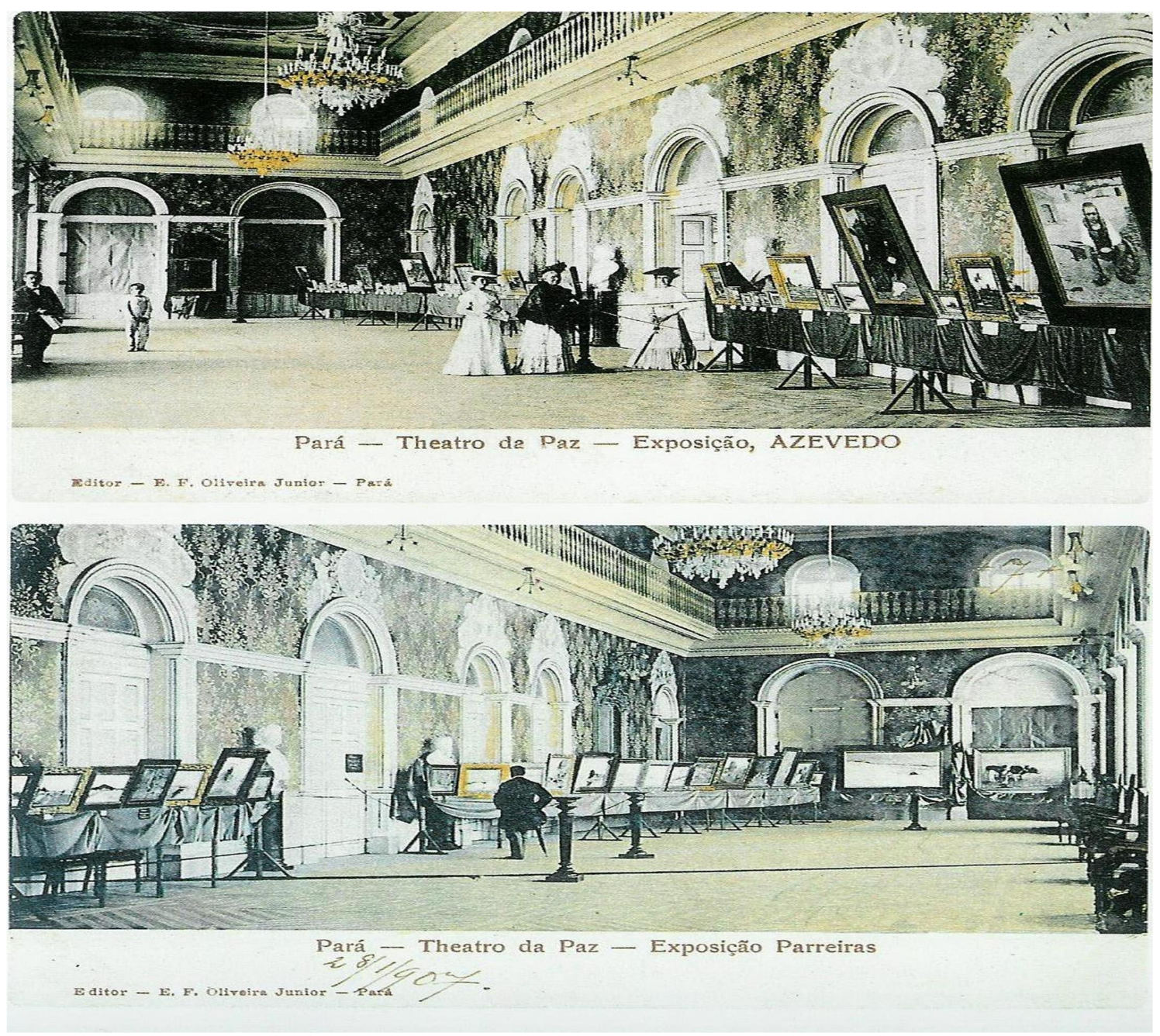

Fonte: Belém (1998).

Foto 5 - Praça Batista Campos (Antes Parque).

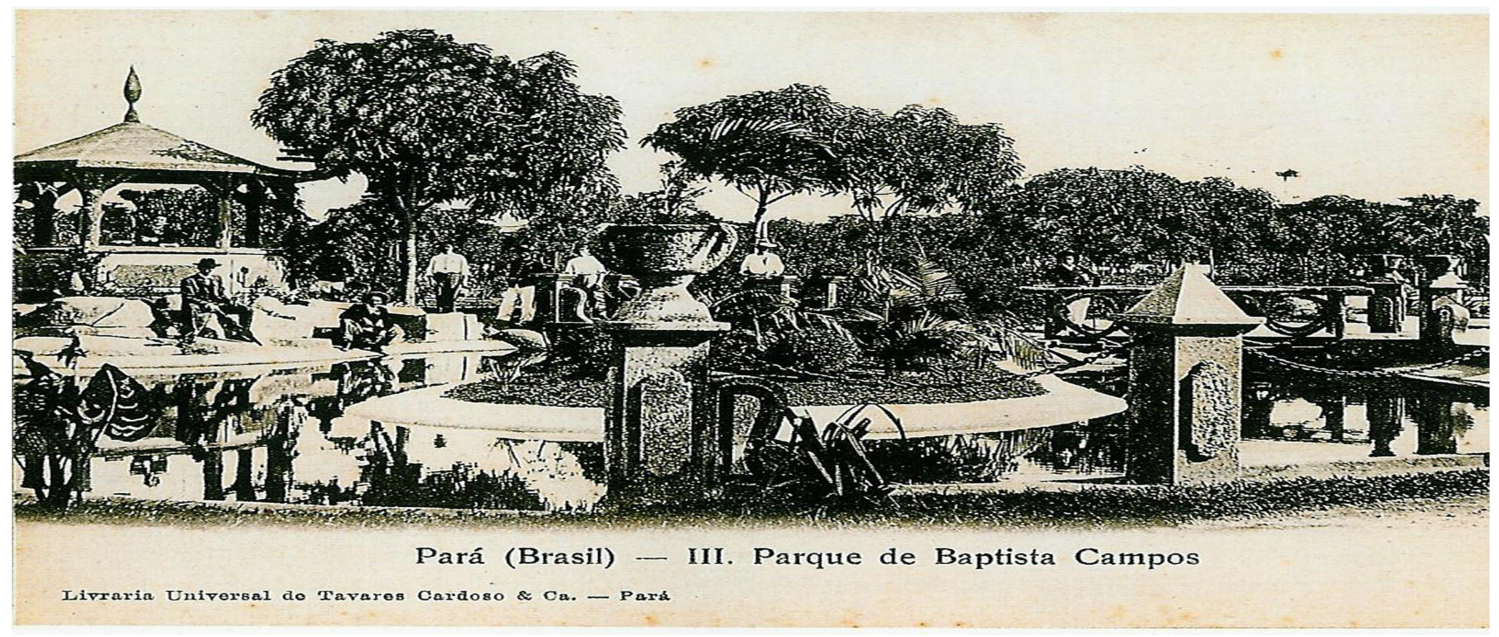

Fonte: Belém (1998). 
Os largos ou praças não eram lugares públicos de lazer criados para a frequência do povo, mas espaços para se demonstrar o status burguês e serviam para ver e ser visto, sendo este o novo hobby da elite. A praça se transformou num lugar onde, por meio da observação do vestuário de seus visitantes, era possível se identificar a que classe cada um pertencia, distinguindo gente do povo e burgueses (BAHIA, 2012).

Para além desses espaços formais como os largos e praças, que foram progressivamente institucionalizados para a prática do lazer na cidade, as manifestações culturais das classes populares apresentaram resistência em terreiros, espaços domésticos e áreas alagadas. Isso porque estas áreas encontravam-se distantes dos olhos vigilantes do poder dominante. Neste contexto, reafirma-se que o lazer é um fenômeno social presente em todas as classes e espaços.

Os largos, que atualmente são conhecidos sob a denominação de Praças Públicas ${ }^{6}$, eram tidos como uma espécie de pátios das igrejas e utilizados pelos sacerdotes para agregar pessoas e disseminar a filosofia católica cristã na região. De acordo com Macedo e Robba (2009), a praça assumiu diferentes funções, quando compreendida a partir da evolução urbana das cidades brasileiras. No período colonial, esteve especialmente a serviço de fins religiosos e militares, utilizada como meio de convívio social e caracterizada por uma estrutura física marcadamente livre de muros, grades e cercas.

No Mapa 3, construído a partir de levantamento bibliográfico ancorado em pesquisa de Soares (2009), é possível se verificar a representação do processo de conformação das primeiras praças em Belém. É possível perceber que esses primeiros espaços públicos, que atualmente são utilizados com fins de vivências de lazer, foram construídos em sintonia com o processo de expansão do Vilarejo, tendo início nos bairros da Campina e da Cidade Velha. Aparecem datados entre os séculos XVII e XVIII, ainda no período colonial, sob a denominação de "largos", quando a coroa Portuguesa, objetivando a ampliação da ideologia católica-cristã no vilarejo, obteve nas ordens religiosas, um importante aparato consolidador de seus interesses no novo território.

O referido mapa demonstra a localização de 13 largos, com as suas respectivas datas de fundação e nomenclaturas atuais, a citar: Forte do Presépio; Largo da Sé; Largo da República do Líbano; Largo do Carmo; Praça Dom Macedo Costa; Praça Visconde do Rio

\footnotetext{
6 "Praças são espaços livres públicos urbanos destinados ao lazer e ao convívio da população, acessíveis aos cidadãos e livres de veículos, definidos pela malha urbana formal e que não ocupem mais 2 ou 3 quadras consecutivas" (MACEDO; ROBBA, 2009, p. 5).
} 
Branco; Praça Barão do Guajará; Largo do Rosário da Campina; Praça Amazonas; Praça do Arsenal; Praça Maranhão; Praça Dom Pedro II; Praça da República.

Atualmente, todos esses espaços são denominados de Praças Públicas e servem ao lazer e ao turismo em Belém. O Largo da Sé é mais conhecido como Praça Frei Caetano Brandão e possui um importante destaque na produção do lazer local, por sua localização estratégica, no centro histórico, compondo, juntamente com outros espaços, como por exemplo a Igreja da Sé e o Forte do Presépio, um complexo arquitetônico e de lazer na cidade.

Se fala cada vez mais a palavra requalificação ao invés de planejamento da cidade, sob a justificativa de necessária ampliação de estratégias de flexibilização, aplicadas ao contexto do urbano. Neste sentido, o termo requalificação tem sido empregado para fazer referência a projetos arquitetônicos que objetivam modificar a funcionalidade do espaço, dado aos mesmos novos papéis no contexto urbano como, por exemplo, o turismo. 
Mapa 3: Primeiras Praças de Belém.

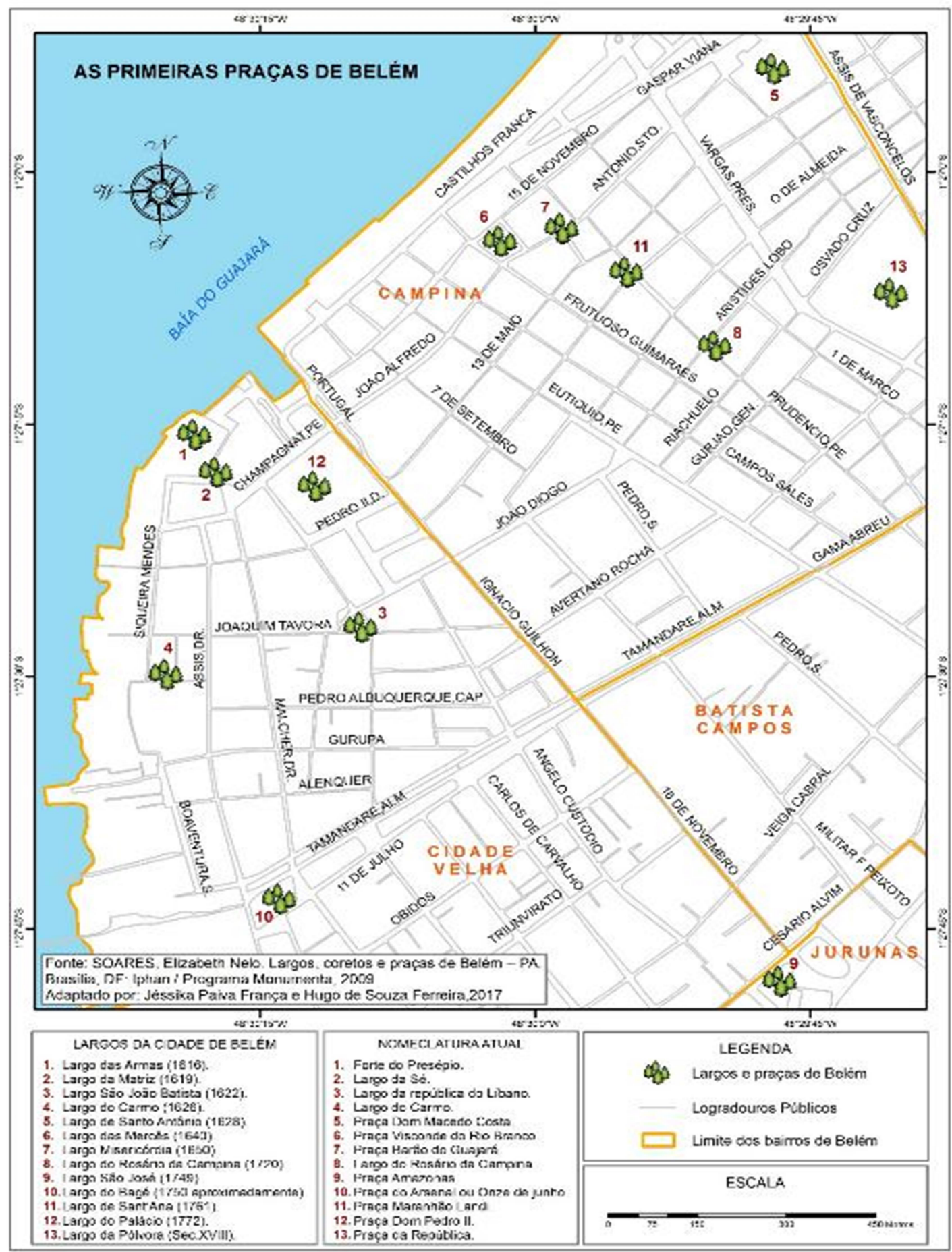

Fonte: França (2018). Adaptado a partir do trabalho de Soares (2009).

Segundo dados do Imazon (2003), 25\% das praças de Belém teriam sido criadas antes da década de 1950. No gráfico 1, é possível se verificar que os séculos XVII e XVIII foram os mais representativos em termos de conformação de espaços públicos que atualmente são 
utilizados para fins de lazer e turismo na cidade de Belém. "De 1950 a 1960 criaram-se 82 mil $\mathrm{m}^{2}$ de novas praças; posteriormente, na década de 70 , houve um incremento de $47 \mathrm{mil} \mathrm{m}^{2}$ de praças e, na década de 90, 135 mil m²" (IMAZON, 2003, p. 41).

Gráfico 1: Conformação de Espaços Públicos em Belém por século.

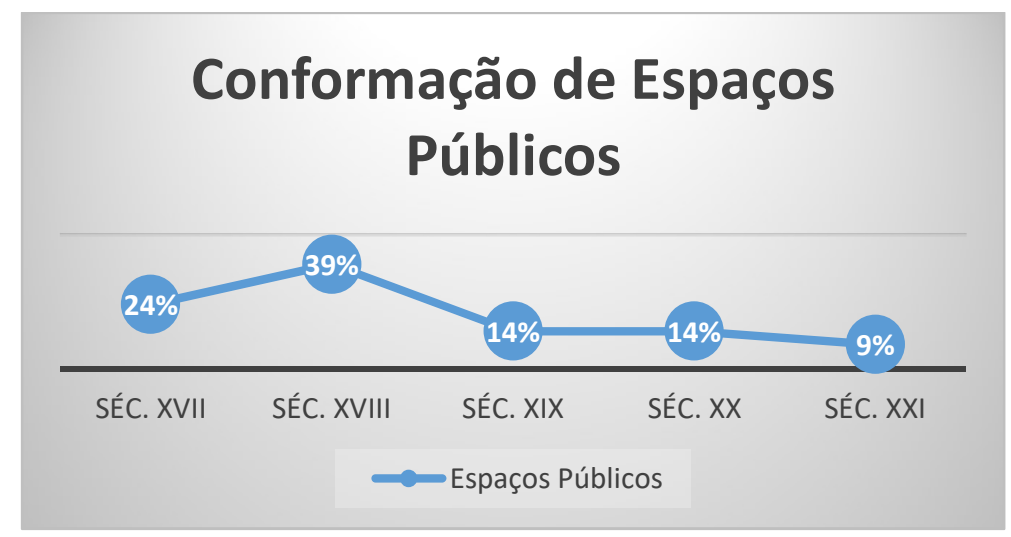

Fonte: França (2018).

No ano de 2000, observa-se um retorno no crescimento desses espaços na cidade, o que pode ser comprovado no Gráfico 2. “[...] Nesse período, a área de praças cresceu $53 \%$ na cidade de Belém, atingindo $0,61 \mathrm{~m}^{2}$ por habitante. Vale lembrar que este número ainda está abaixo do índice per capta $\left(0,71 \mathrm{~m}^{2}\right)$ registrado em 1950 [...]” (IMAZON, 2003, p. 37).

Gráfico 2: Área de praças por década.

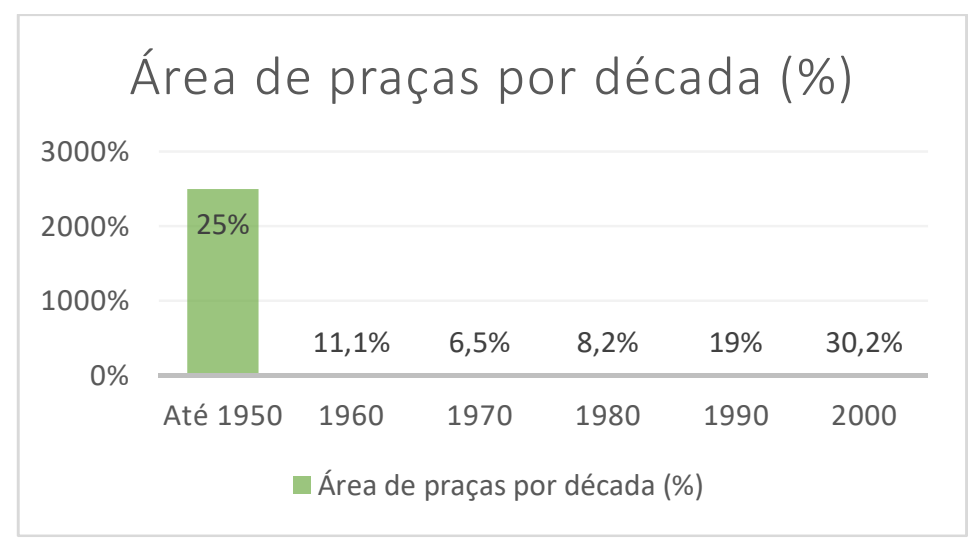

Fonte: Imazon (2003, p. 42).

Em pesquisas realizadas por Bahia et al. (2008), ao analisarem os diversos espaços e equipamentos de lazer de Belém, os autores identificaram a existência de uma concentração de equipamentos específicos e não específicos de lazer no centro urbano de 
Belém e nos bairros mais centrais da cidade; além de uma visível falta de divulgação à população de alguns equipamentos e de programações culturais existentes nesses. As praças se caracterizam como o equipamento em maior quantidade na cidade e com uma distribuição mais igualitária nos bairros (Quadro 1).

Quadro 1 - Distribuição dos equipamentos de Lazer em Belém.

\begin{tabular}{|c|c|c|c|c|c|c|c|c|c|c|c|}
\hline Bairro & Pra & Mus & Tea & Cin & Par & Mer & For & $\lg r$ & Bib & $\begin{array}{c}\text { Memo/ } \\
\text { Comp } \\
\text { Cult- } \\
\text { Esport. }\end{array}$ & Shop \\
\hline Barreiro & 01 & ----- & --- & --- & ----- & ----- & ----- & ----- & ----- & ----- & ----- \\
\hline Batista Campos & 04 & ----- & 01 & 05 & ----- & ----- & ----- & ----- & 01 & ----- & 01 \\
\hline Benguí & 07 & ----- & --- & --- & ----- & ----- & ----- & ----- & ----- & ----- & ----- \\
\hline Campina & 21 & 02 & 03 & 01 & ----- & 03 & ----- & 02 & 01 & 01 & ----- \\
\hline Canudos & 02 & ----- & --- & --- & ----- & ----- & ----- & ----- & ----- & ----- & ----- \\
\hline Atalaia & ---- & ----- & --- & 09 & ----- & ----- & ----- & ----- & ----- & ----- & 01 \\
\hline Cidade Velha & 11 & 06 & --- & $\begin{array}{ll}-- \\
\end{array}$ & ----- & $\begin{array}{ll}---- \\
\end{array}$ & 01 & 03 & ------ & 02 & $\begin{array}{l}----- \\
\end{array}$ \\
\hline Condor & 01 & $\begin{array}{l}---- \\
\end{array}$ & --- & --- & ----- & ----- & ----- & ----- & $\begin{array}{l}---- \\
\end{array}$ & ----- & ----- \\
\hline Coqueiro & 20 & ----- & --- & --- & ----- & $\begin{array}{l}---- \\
\end{array}$ & ----- & ----- & ----- & ----- & ----- \\
\hline Cremação & 02 & ----- & ---- & ---- & ------ & ----- & ----- & ----- & ------ & ------ & - ---- \\
\hline Curió-Utinga & 04 & +---- & --- & --- & 01 & +---- & 01 & $\begin{array}{l}---- \\
\end{array}$ & ----- & ----- & ----- \\
\hline DAICO & 09 & ----- & --- & --- & ----- & ----- & ----- & ----- & 01 & 01 & ----- \\
\hline DAMOS & 16 & ----- & --- & --- & ----- & ----- & ----- & ----- & ----- & 01 & ----- \\
\hline DAOUT & 03 & ----- & --- & --- & ----- & ----- & ----- & ----- & ----- & 01 & ----- \\
\hline Fátima & 07 & ----- & --- & --- & ----- & ----- & ----- & ----- & ----- & ----- & ------ \\
\hline Guamá & 04 & ----- & --- & --- & ----- & ----- & ----- & ----- & ----- & ----- & ------ \\
\hline Jurunas & 09 & 02 & --- & --- & 01 & 01 & ----- & ----- & ------ & ----- & ------ \\
\hline Mangueirão & 03 & ----- & --- & --- & ----- & ----- & ----- & ----- & ----- & 01 & ----- \\
\hline Maracangalha & 04 & ------ & ---- & ---- & ------ & ------ & ----- & ----- & ------ & ------ & ------ \\
\hline Marambaia & 36 & ----- & --- & --- & ----- & ---- & ----- & ----- & ----- & 01 & ----- \\
\hline Marco & 05 & ----- & 01 & --- & ----- & ----- & ----- & ----- & ----- & 02 & ---- \\
\hline Miramar & 01 & ----- & --- & --- & ----- & $\begin{array}{ll}---- \\
\end{array}$ & ----- & ----- & ----- & ----- & ------ \\
\hline Montese & 04 & ----- & --- & --- & ----- & ----- & ----- & ----- & ----- & ----- & ----- \\
\hline Nazaré & 02 & 05 & 01 & 04 & ----- & ------ & ----- & 01 & 03 & 03 & ------ \\
\hline Pedreira & 04 & ----- & $\begin{array}{ll}-- \\
\end{array}$ & --- & $\begin{array}{ll}---- \\
\end{array}$ & $\begin{array}{ll}---- \\
\end{array}$ & ----- & $\begin{array}{ll}---- \\
\end{array}$ & ----- & 01 & $\begin{array}{l}----- \\
\end{array}$ \\
\hline Pratinha & 01 & ----- & --- & --- & ----- & ----- & ----- & ----- & ----- & ----- & ----- \\
\hline Reduto & 04 & ----- & --- & 01 & ----- & ----- & ----- & ----- & ----- & 01 & ------ \\
\hline Sacramenta & 05 & ----- & --- & --- & ----- & ----- & ----- & ----- & ----- & ----- & ---- \\
\hline São Brás & 07 & ----- & --- & 01 & 01 & ---- & ---- & ---- & ---- & 01 & ---- \\
\hline Souza & 10 & 01 & --- & --- & ----- & ----- & ----- & ----- & ----- & ----- & ------ \\
\hline Tapanã & 09 & $\begin{array}{ll}---- \\
\end{array}$ & --- & --- & $\begin{array}{ll}---- \\
\end{array}$ & ----- & ----- & ----- & ----- & ----- & ---- \\
\hline Telégrafo & 03 & ----- & --- & --- & ----- & ----- & ----- & ----- & ----- & ----- & ------ \\
\hline Umarizal & 04 & 01 & --- & --- & ----- & ----- & ----- & ----- & ----- & ----- & ----- \\
\hline Val-de-Cans & 06 & 01 & --- & --- & ----- & ----- & ----- & ----- & ----- & ----- & ----- \\
\hline
\end{tabular}




\begin{tabular}{|c|c|}
\hline 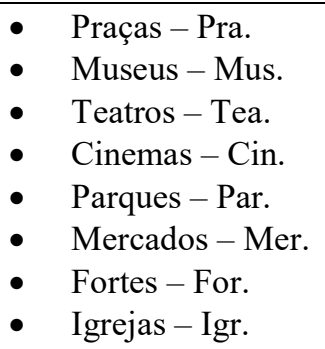 & $\begin{array}{ll}\text { - } & \text { Bibliotecas - Bib. } \\
\text { - } & \text { Memorial/Complexo Cultural-Esportivo - } \\
\text { - } & \text { Semo/Comp. Cult. Esport } \\
\text { - } & \text { DAICO - Distrito de Icoaraci } \\
\text { - } & \text { DAMOS - Distrito de Mosqueiro } \\
\text { - } & \text { DAOUT= Distrito de Outeiro }\end{array}$ \\
\hline
\end{tabular}

Fonte: Bahia et al.(2008, p. 71-72).

\section{CONSIDERAÇÕES FINAIS}

Nesta pesquisa, identificou-se que as praças de Belém apresentaram um papel de destaque na produção urbana local, bem como em outras cidades brasileiras, servindo inicialmente a fins de expansão territorial e religiosa. Progressivamente, foi se configurando como um espaço de encontro entre diferentes, com reais possibilidades para o embelezamento urbano e práticas de lazer.

Atualmente esse tipo de espaço (praça) é entendido como um espaço representativo da democracia na cidade, por ser gratuito e estar, em sua maioria, livre dos olhares vigilantes da segurança terceirizada.

A conformação urbana de Belém, como foi aqui apresentada, com especial destaque ao papel desempenhado por espaços como largos e praças, objetivou identificar os principais elementos que caracterizam a relação atual entre a praça pública e a cidade no âmbito da produção urbana local.

Os processos construtivos de cidade, sejam materiais ou imateriais, são reformulados processualmente para a continuidade do modo de produção e sustentação de suas bases financeiras. Para Pádua (2015), há necessidade de identificação das bases ideológicas da produção do espaço, considerando a importância das mesmas para a produção da vida social na metrópole.

A hierarquia dos lugares e dos usos decorrentes da centralidade é perceptível na cidade contemporânea; uma das explicações dada a este fato é a redefinição funcional do centro no processo de estruturação do espaço urbano, sendo este um processo essencial para a dinâmica das cidades e fluidez do capital no atual modo de produção.

O espaço público, em especial a praça pública (foco dessa pesquisa), pressupõe muito além da forma física. Abrange questões relacionadas diretamente à diversidade de usos e significados dados por seus usuários, sendo, portanto, considerada, uma categoria constitutiva de cidade. Neste âmbito de discussões, a conformação e reconfiguração de espaços públicos 
de lazer na cidade contemporânea é resultante de processos decorrentes das formas de uso espacial pela sociedade, que nele se materializa, conduzidas por processos ideológicos focados no consenso sobre a necessidade de melhoria da qualidade ambiental e de vida da sociedade.

Entendidos também como áreas de sociabilidade e lazer, os espaços públicos são indispensáveis ao cotidiano das cidades e também podem ser percebidos com dupla função, pois, de acordo com Figueiredo (2008), ao mesmo tempo em que proporcionam lazer aos moradores, podem ser vistos como uma pequena amostra cultural do que determinada sociedade possui, atraindo os visitantes que querem conhecer o que pode ser classificado como típico do lugar.

Predominou na província de Belém do Grão Pará, entre os séculos XVII e XIX, um olhar pejorativo sobre o rio e as águas próximas a ele, que pode ser associado aos medos e traumas que as grandes navegações colonizadoras geraram na humanidade. Tragédias marítimas decorrentes de naufrágios, proliferação de doenças e náuseas do mar são apenas alguns dos exemplos citados por Corbin (1989), que fazem muito sentido neste artigo, pois trata da elevação do espaço formal de lazer e da depreciação de práticas culturais manifestadas pelas classes populares, a exemplo do banho de rio e rodas de batuque.

Os espaços de uso hegemônico na cidade, quando olhados sob o ponto de vista da produção urbana, revelam apenas elementos valorativos de embelezamento urbano e desenvolvimento econômico de uma época. Permanecem ocultos as lutas de classes e formas de resistências, como foi possível identificar nas manifestações de lazer e sociabilidades das classes populares, presentes nos séculos que decorreram a fundação da cidade.

\section{REFERÊNCIAS}

ANDRADE, Fabiano Homobono Paes de. De São Braz ao Jardim Público - 1887-1931: um ramal da estrada de ferro de Bragança em Belém do Pará. Tese de Doutorado. São Paulo, PUC - Programa de Pós-graduação em História, 2010.

ALMEIDA, Conceição Maria Rocha de. Belém do Pará uma Cidade entre as águas: História, natureza e definição territorial em princípios do século XIX. SP: Anais do XXVI Simpósio Nacional de História - ANPUH, 2011.

BAHIA, Mirleide Chaar et al. Os espaços e equipamentos de lazer das Cidades: o caso de Belém. In: FIGUEIREDO, Silvio L. Turismo, lazer e planejamento urbano e regional. Belém: NAEA/ANPUR, 2008. 
BAHIA, Mirleide Chaar. O Lazer e as relações socioambientais em Belém - Pará. Tese de Doutorado. Belém, Núcleo de Altos Estudos Amazônicos, Universidade Federal do Pará (UFPA) - Programa de Pós-graduação em Desenvolvimento Sustentável do Trópico Úmido, 2012.

BELÉM, Intendência Municipal de. Relatório apresentado ao Conselho Municipal de Belém por José Antônio Lemos. Belém, 1902.

BELÉM da Saudade: a memória da Belém do início do século em cartões-postais. 2. ed., rev. aum. Belém: SECULT, 1998. 278 p.

CORRÊA, Roberto Lobato. O espaço urbano. SP: Ed. Ática, 1989.

CRUZ, Ernesto. História de Belém. Belém: UFPA, 1973. 2 v.

FIGUEIREDO, Silvio L. Espaços Públicos nas Cidades: notas sobre o ordenamento, acessibilidade e turistificação. In: FIGUEIREDO, Silvio (Org.). Turismo, lazer, planejamento urbano e regional. Belém: UFPA; NAEA, 2008. p. 79-92.

FILHO, Augusto Meira. Evolução Histórica de Belém do Grão Pará. 1976. Fundação e História. $1^{a}$ edição. Belém: Gráfica e Editora Globo, 1976.

FRANÇA, Jéssika Paiva. Espaços públicos de lazer e cidade: Desdobramentos em BelémPA, o caso orla portal da Amazônia. Tese de Doutorado. São Paulo, Instituto de Arquitetura e Urbanismo da Universidade de São Paulo (USP) - Programa de Pós-Graduação em Arquitetura e Urbanismo, 2018.

IMAZON. Belém sustentável. Belém: Imazon, 2003.

LOBATO, Célio C. de Queiroz. O Plano Urbano de Antônio Lemos: A Planta de Belém de 1905. LOBATO, Célio C. de Queiroz [et. Al.]. Um olhar sobre aspectos da infraestrutura e do planejamento urbano em Belém do Pará. Belém: Ed. CESUPA, 2005.

MACEDO, Silvio Soares, ROBBA, Fábio. Praças brasileiras. SP: Edusp, 2009.

MOREIRA, Eidorfe. Belém e sua expressão geográfica. Belém: UFPA, 1966.

MOREIRA, Eidorfe. Geografias Mágicas - Ensaios. In: MOREIRA, E. Obras reunidas de Eidorfe Moreira. Belém: CEJUP, 1989, Vol. VII.

PADUA, Rafael Faleiros de. Produção estratégica do espaço e os 'novos produtos imobiliários'. In: CARLOS, Ana Fani; ALVAREZ, Isabel Pinto; VOLOCHKO, Danilo. A cidade como negócio. SP: Contexto, 2015.

PENTEADO, Antônio Rocha. Belém do Pará. Estudo da Geografia Urbana. Vol. 1. Coleção Amazônica. Série José Veríssimo. Belém: UFPA. 1968.

SARGES, M. de N. Belém: Riquezas produzindo a Belle-époque (1870-1912). Belém: PakaTatu, 2000.

SARGES, M. de N. Belém: Riquezas produzindo a Belle-époque (1870-1912). Belém: PakaTatu, $3^{\mathrm{a}}$ ed. 2002. 
SOARES, Elizabeth Nelo. Largos, coretos e praças de Belém - PA. Brasília, DF: Iphan / Programa Monumenta, 2009.

STIEL, Waldemar Corrêa. História do Transporte Urbano no Brasil. Brasília: EBTU, 1984.

TOCANTINS, Leandro. Santa Maria de Belém do Grão Pará. Belo Horizonte: Editora Itatiaia, 1987.

VALENTE, José Duarte. A história nas ruas de Belém: Cidade Velha. Belém: CEJUP, 1993, p. 9 - 11.

Recebido em: 22/04/2019

Aprovado em: 28/07/2019 